\title{
IMPLEMENTATION OF THE RESIDUAL PRODUCTIVITY PRINCIPLE IN LAND VALUING METHODS
}

\author{
Drapikovskyi O., Associate Professor of Urban Economy Department \\ E-mail:a_drapikovsky@hotmail.com
}

Ivanova I., Associate Professor of Urban Economy Department E-mail:i_ivanova@hotmail.com Kiev National University of Construction and Architecture

Land valuation is based on numerous principles, among which the principle of residual productivity plays a leading role. According to this principle, the current land value is determined by the residual income from its possible future use in the future, taking into account the costs and the time required to obtain this income. In addition, the residual productivity principle is fundamental in revealing the immanent uncertainty of land valuation due to the multiplicity of its value, each of which will be true in assumptions and false in other cases.

The application of this principle in the land valuation has become constitutional in the formation and development of its methodological apparatus.

The article discusses the evolution of land valuation methods based on the residual productivity principle - from traditional extraction methods and residual capitalization to discounted cash flow methods - and analyzes the main advantages and limitations of their use in valuation practice. The necessity of moving from deterministic to stochastic cash flows models and supplementing them with optional pricing models, which best reflect the modern understanding of the residual nature of land value and taking into account its inherent uncertainty, has been proved.

Keywords: residual land productivity, uncertainty, deterministic and stochastic cash flow models, optional pricing models.

Formulation of the problem. Valuation, including the estimate of value, is based on numerous principles that reflect the nature of the asset, the external 
conditions of valuation and the characteristics of the valuer. Adherence to these principles not only effectively organizes the process of analytical research, but also serves as a strong argument for the validity of the valuation and the reliability of its results.

One of the most common principles in valuation practice is the principle of surplus productivity or residual productivity. It is used in selecting the highest and best use, in assessing the economic feasibility of investment projects, in estimating the value of real property with potential for development (including unfinished construction properties; properties whose land improvements have already exhausted their economic life; assets that do not have a market at the date of valuation but may have one when used alternatively); as well as start-ups; intangible assets, real options and, above all, land valuation.

According to this principle, the asset value being measured in its present condition is determined by the residual income from its possible future use, taking into account the cost and time required to obtain that income, which ultimately determines the residual nature of the asset value. These requirements are fully met by valuing the vacant land.

The understanding that the land value is explained by the benefits they derive from its use has long been formed. Back in ancient times, landowners, filling in a tax return, wrote that they expected to get a certain crop of wheat or grapes, so they would pay such a tax for the land. And after David Ricardo's classic work, On the Principles of Political Economy and Taxation (1817), which argued the derivative nature of land value from the nature of its use, the residual productivity principle becomes decisive in land valuation.

In this case, it is the residual productivity principle that is fundamental in the disclosure of the immanent uncertainty of the land valuation, caused by the multiplicity of its value indications, each of which will be true under one assumption and false in other cases.

The uncertainty is inherent in any valuation. Disclosures of its nature, sources of origin, methods of identification and measurement are devoted to publications of 
domestic and foreign authors $[1-7]$. However, in the land valuation, where its causes are systemic - objective, subjective and model - character, uncertainty, rather, an attempt to overcome it, in our opinion, is a driving force in the formation of principles and improvement of valuation methods and procedures.

The influence of the uncertainty of the land valuation on the evolution of its methods has already been the subject of consideration in the authors' publications [8; 9]. Therefore, the main material of this article would like to focus on the problem of implementing the residual productivity principle in land valuing methods.

Purpose of the study. Revealing the role of the residual productivity principle in the evolution of methods for determining the land value.

\section{Results of the study and discussion.}

1. Premise of the land value. The land value is a measure of its utility. In other words, in order for land to acquire value, it must be used or intended for use (agriculture or forestry, development, etc.). In any case, it must be allocated to a separate parcel, set rights and obligations in respect of it and be improved accordingly, i.e. to turn it into a real property product.

It is precisely as a component of real property to land that supply and demand is formed and it is in real property that the land acquires value, which determines by the residual income from land use (from the sale of the created product) after deducting all costs associated with its receipt, including the finance costs and the profit of the entrepreneur [10, p.15].

It does not matter what is the subject of consideration - the land rent (annual value) or the land value (capital value) - since both arise as a result of land use.

That is, the land use should be considered as the premise of the land value. However, given that the land can theoretically have an unlimited number of uses, the same parcel of land will be characterized by the different value indications, indicating the objective nature of the land valuation uncertainty.

The objective nature of the land valuation uncertainty is related to the problem of choosing the value indication, which was initially a legal and then an economic 
solution in principle, in which the land, even if it is improved, is considered vacant and open to the highest and best use that provides the highest land value.

Annual Value

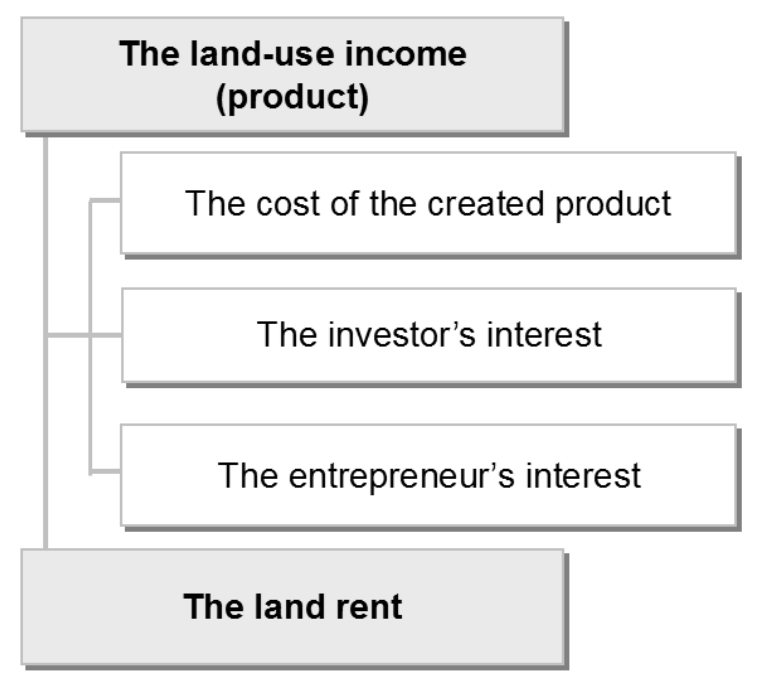

Capital Value

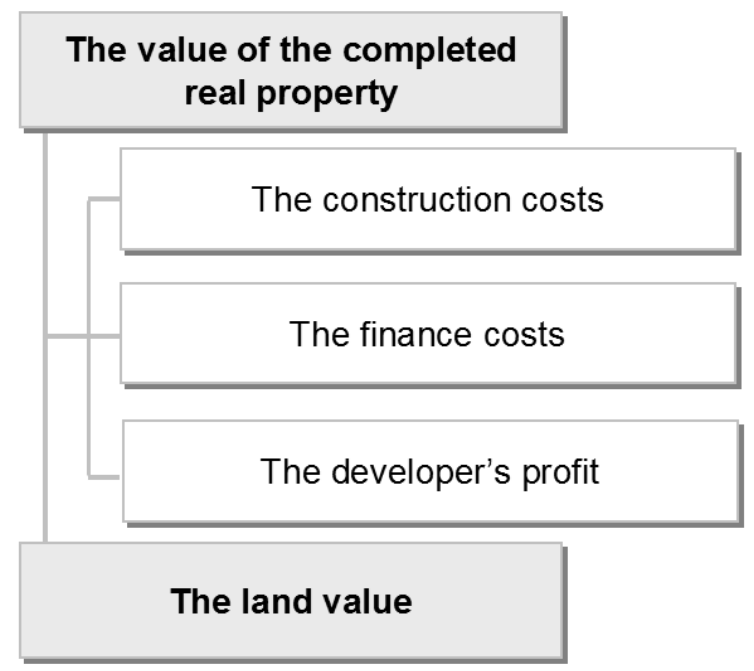

Fig. 1 The residual nature of land value

Particularly acute, this problem arose when resolving the issue of the fair amount of land seizure compensation. In particular, in the United States the principle of highest and best use was legally enshrined in 1878 [11, p. 119].

The highest and best use is adequate from the point of view of market participants and should be considered as the basis for estimating the market land value, which can be paid not only by the specific buyer but also by its competitors. In other words, to estimate the market land value, it is necessary to consider all possible (existing and alternative) land uses from the point of view of achieving its maximum productivity. However, those uses that require the complete release of the site from existing improvements should not be excluded from consideration.

Note that the highest and best use is not determined based on the subjective opinion of the landowner or user, developer or appraiser, but is formed by competitive market forces and is limited to the established zoning plan with the relevant land use regulations.

With the widespread implementation of zoning rules and requirements to comply with them (in Ukraine this requirement is stipulated by the Land Code and the Law of Ukraine "On Regulation of City Planning Activity"), the choice of the 
highest and best use began to determine of the function and intensity of land use - the main factors affecting its value. This gave the land valuation the necessary certainty, excluding from the case of under-improved or over-improved real property (the balance principle).

It is typical that in editions of the International Valuation Standards 2010`s, the terms concerning the highest and best use as "the most probable use ..." were deleted to emphasize the uniqueness of choice ${ }^{1}$.

2. Problem of the shared residual. The principle of residual productivity is linked to another problem - the problem of shared residual, - which was pointed out in the early nineteenth century by David Ricardo.

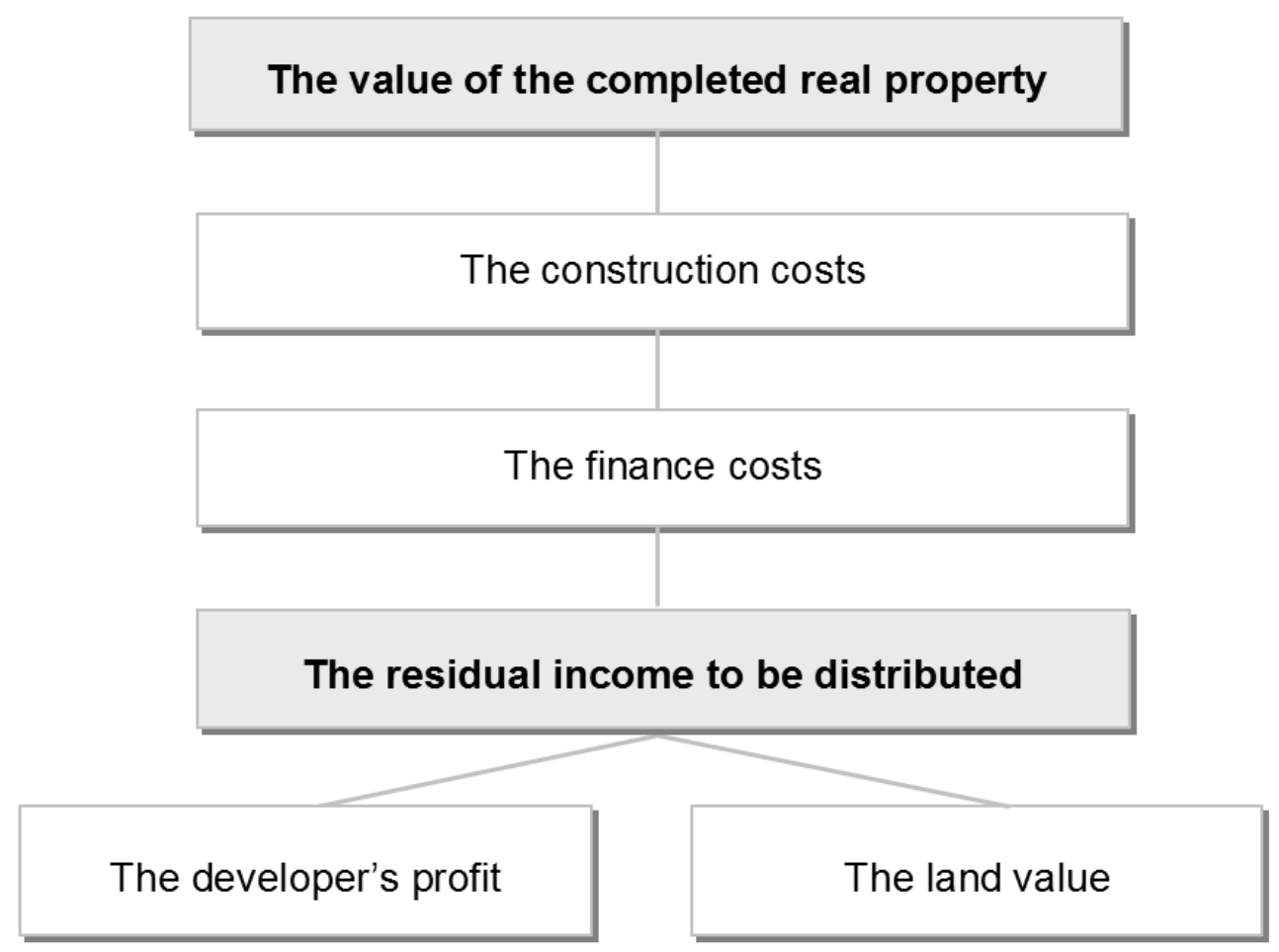

Fig. 2 The residual income to be distributed

The fact is that the residual nature has not only the land value, but also the entrepreneurial profit, which together form the shared residual to be distributed according to the interests of the landowner and the interests of the entrepreneur (developer). This leads to the land valuation subjective uncertainty, since each party

\footnotetext{
${ }^{1}$ How, when land valuation, the requirement of IVS 2017 for the need to take into account not only the existing legal restrictions on the use of the asset, but also the likelihood that these restrictions will change [12, p. 32], will be considered later
} 
will have its own judgment about the usefulness of the asset and act on its own behalf.

It is considered that a competitive market helps to reach a compromise between the interest of the entrepreneur and interest of the landowner by establishing a normal profit and market land value, reflecting the viewpoint not of a particular person or group of persons, but of all participants of the market.

Therefore, as early as the nineteenth century, the substitution principle and methods of market comparisons - sales comparison and statistical market analysis began to be used in land valuation, and when market evidence was clearly insufficient, they resorted to contingent valuation.

- statistical market analysis - the absolute indication of the factors

$$
P_{i}=\beta_{0}+\sum_{j=1}^{m} \beta_{j} x_{i j}+\varepsilon_{i}
$$

- sales comparison - the compared distinction of the factor indications

$$
P_{0}-P_{i}=\sum_{j=1}^{m}\left(x_{0 j}-x_{i j}\right) \cdot v_{j}
$$

\section{Fig. 3 The models of market comparison}

Due to their transparency, minimization of assumptions and the possibility of direct market confirmation, the methods of market comparison had obvious advantages and quickly found their supporters among the land valuers. As a result, two classes of valuing models, have been disseminated in land valuation: market comparison and residual productivity.

3. Comparative and residual land value. The authors' research shows that, in practice, the sharing of market comparison and residual productivity models to valuation the same site often does not provide a definite result, but defines a certain land value range, set by the minimum possible value for the seller and the maximum possible for the buyer, indicating model uncertainty of land valuation.

If the buyer's intended use does not meet the requirements of best and most efficient use, then the residual value of the land will be less than the comparative 
value of vacant land on the market, based on their best and most efficient use and most likely the normal profit of the developer will not be received by the buyer.

If the market has not yet reacted to the emergence of new, more efficient, buyerprovided use, then the land value on the market will be less than the residual land value in an innovative development project, and the buyer can count on additional, economic, profit.

$$
\begin{aligned}
& V_{L_{i}}=V_{O_{i}}-\left(V_{C_{i}}+V_{F_{i}}+V_{D_{i}}\right) \\
& V_{L_{i}}=P_{i}+\sum_{j=1}^{m} \Delta x_{i j} \cdot v_{j}-\left\{\begin{array}{l}
\text { economic profit } \\
\text { normal profit }
\end{array}\right. \\
& V_{L_{i}}=V_{O_{i}}-\left(V_{C_{i}}+V_{F_{i}}+V_{D_{i}}\right) \downarrow\lceil\text { economic losses }
\end{aligned}
$$

Fig. 4 The ratio of comparative and residual land value

Interestingly, almost fifty years ago, in 1971, Jean-Claude Dutailly came to the conclusion that the final land price fluctuates between its market price and the maximum price the buyer is prepared to pay based on the construction conditions: the expected income from the erected building minus the costs for their construction and other additional costs [13].

Therefore, the land value will reflect the parity of the buyer and seller's interests only when the estimated development of the appraised site is similar to the development of such sites and provided that market participants consider such development to be the highest and best use.

The last point is important methodologically, since the market value is always estimate based on the principle of highest and best use of the asset, and if the asset has potential for development, then the value judgment of such an asset will always be based on the concept of residual productivity. This is the paradox of land 
valuation: when valuing land, the site is considered vacant, i.e. without improvement, but to valuing the land, one must know how the site will be improved.

In fact, residual rather than comparative value gives an idea of the price that a hypothetical buyer is willing to pay for the site that is able to provide a reasonable profit for market participants, provided that it is improved accordingly.

It should be noted that International Valuation Standards [14, It. 50] contain reservations regarding the use of the models of market comparison that will be relevant to the valuation of standard vacant site, the intended use of which is similar but will have limited use for vacant site, the proposed improvements of which are heterogeneous. This is due to the fact that the number and set of variables that characterize such assets at first glance, such as differences in permissible use, differences in ground condition, infrastructure arrangements within and outside the site, etc., make the comparisons unreliable.

4. Extraction and residual capitalization. In order to improve the reliability of the land valuation results, along with direct comparison methods, the method of comparing vacant land sales and the subdivision development method, indirect comparison methods have been used: extraction method, allocation method, method of residual for land and income distribution method, - that are aimed at estimate the land value as part of real property, improved in the same way as is foreseen for the vacant land being assessed.

the market of purchase-sale of the improved real property

The extraction method

$$
V_{L_{i}}=V_{O_{i}}-V_{B_{i}}
$$

The allocation method

$$
V_{L_{i}}=V_{O_{i}} \cdot\left(1-B_{i}\right)
$$

the market of lease of the improved real property

The method of residual for land

$$
V_{L_{i}}=\frac{I_{O_{i}}}{R_{O}}-V_{B_{i}}
$$

The income distribution method

$$
V_{L_{i}}=\frac{I_{O_{i}}-V_{B_{i}} \cdot R_{B}}{R_{L}}
$$

\section{Fig. 5 The land valuing methods in the composition of improved real property}


Indirect comparison methods are based on data on sale or lease prices of improved real property, which is more homogeneous than vacant site, but does not guarantee the reliability of the results obtained. Their correct application requires an adequate estimation of the value and cumulative depreciation of land improvements, therefore, most experts recommend to consider the land parcel market whose improvements have not yet been depreciated [11, p. 256].

The unreliability of the results also has a methodological reason: indirect comparison methods base on the value of land improvements, ignoring the fact that land improvements do not have a standalone market, and their value is determined solely by the contribution to the value of improved real property. In addition, land acquires value at the stage of real property development, when the function and intensity of land use are formed, and at the stage of function, this value is only maintained for a time when the existing use corresponds to the highest and best use.

Instead, extraction and residual capitalization methods are relevant and widely used to valuing land improvements of functioning real property when land value is already known.

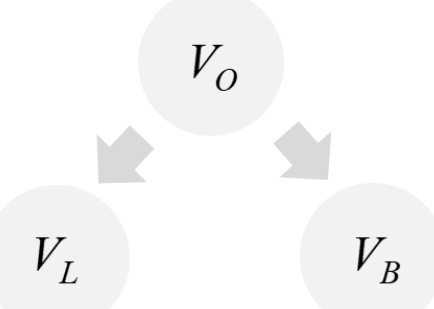

The residual land value

$$
V_{L}=V_{O}-\left(V_{C}+V_{F}+V_{D}\right)
$$

The contributed improvements value

$$
V_{B}=V_{O}-V_{L}
$$

\section{Fig. 6 Asymmetric valuation of physical real property components}

This gives grounds to speak of asymmetric valuation of the physical real property components, according to which the land value has residual character, which corresponds to the residual productivity principle, and the improvements value is contributory and is determined by the difference between the current value of 
improved real property and the market land value at the highest and best use (the contribution principle)

5. Cash flow modeling. Awareness of the spatiotemporal nature of real property contributed to the formation of key assumptions system and the introduction of investment and financial analysis methods based on modeling cash flows that reflect the relationship between the land value and the value of the completed real property, the construction cost, the finance costs and the developer`s profit.

One of the first models of this type was the model proposed by W. Britton, K. Davies and T. Johnson back in the 1960s [15], which first determined the value of the completed real property, then - accumulated over the development period land improvements costs and, finally, the residual for the purchase of the vacant land that was discounted into the land value. At the same time, to take into account the gradual realization of expenses for their compounding, the interest rate was applied for the middle of the real property development period.

On the basis of this model, a whole the collection of deterministic continuous and discrete cash flows models was developed, at which the land value began to be estimate as the difference between the present value of the completed real property and the present value of contracting work. As the discount rate began to be used interest rates, which reflect the investor's and developer's interests.

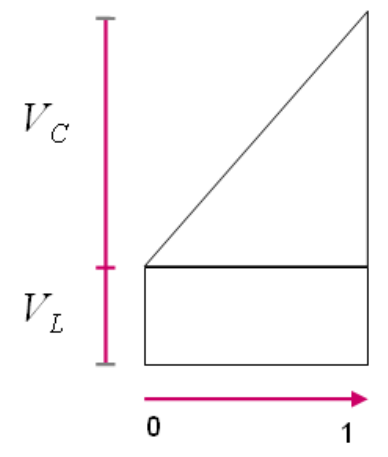

a

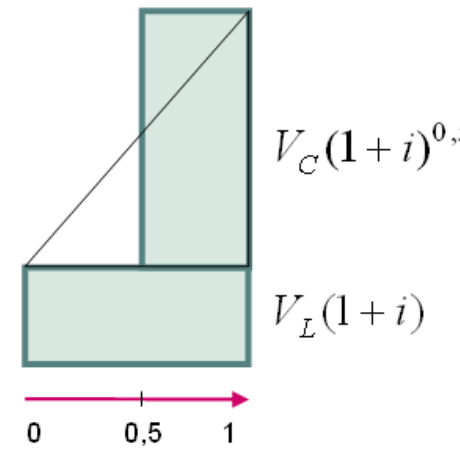

6

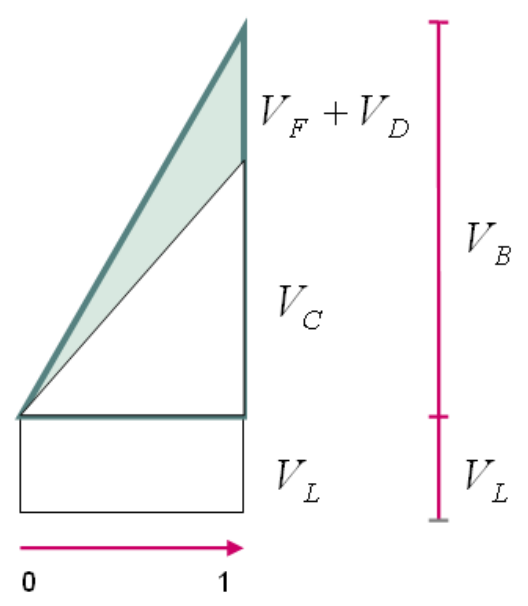

B

a) the cost of land acquisition and its improvement; b) the cost of land acquisition and its improvement, taking into account their financing and the developer's profit;

c) the land value and the land improvements value

Fig. 7 Distribution of the real property development costs over time 
The application of a particular type of model depended on the complexity and duration of the projected development, as well as on the degree of detail required for cash flows by component and period.

The continuous cash flow models have become widespread in the land valuation, with a relatively small period of improvement (development) that does not require a clear timing of payments, for example, in the valuation of site used for annual crops.

Instead, the discrete cash flow models are best suited to valuing land for building, which will last long enough and require a clear allocation of costs over payment periods.

Regardless of the type of model chosen, their application was based on one of two assumptions:

the inputs on the income from the completed real property and the costs associated with that development based on the current values at the date of the special assumption that land improvements have already been completed in accordance with the plan and specifications adopted; or

the inputs to the income from the completed real property and the costs associated with that development are based on the projected values at the date of completion of the land improvement according to the plan and specifications adopted.

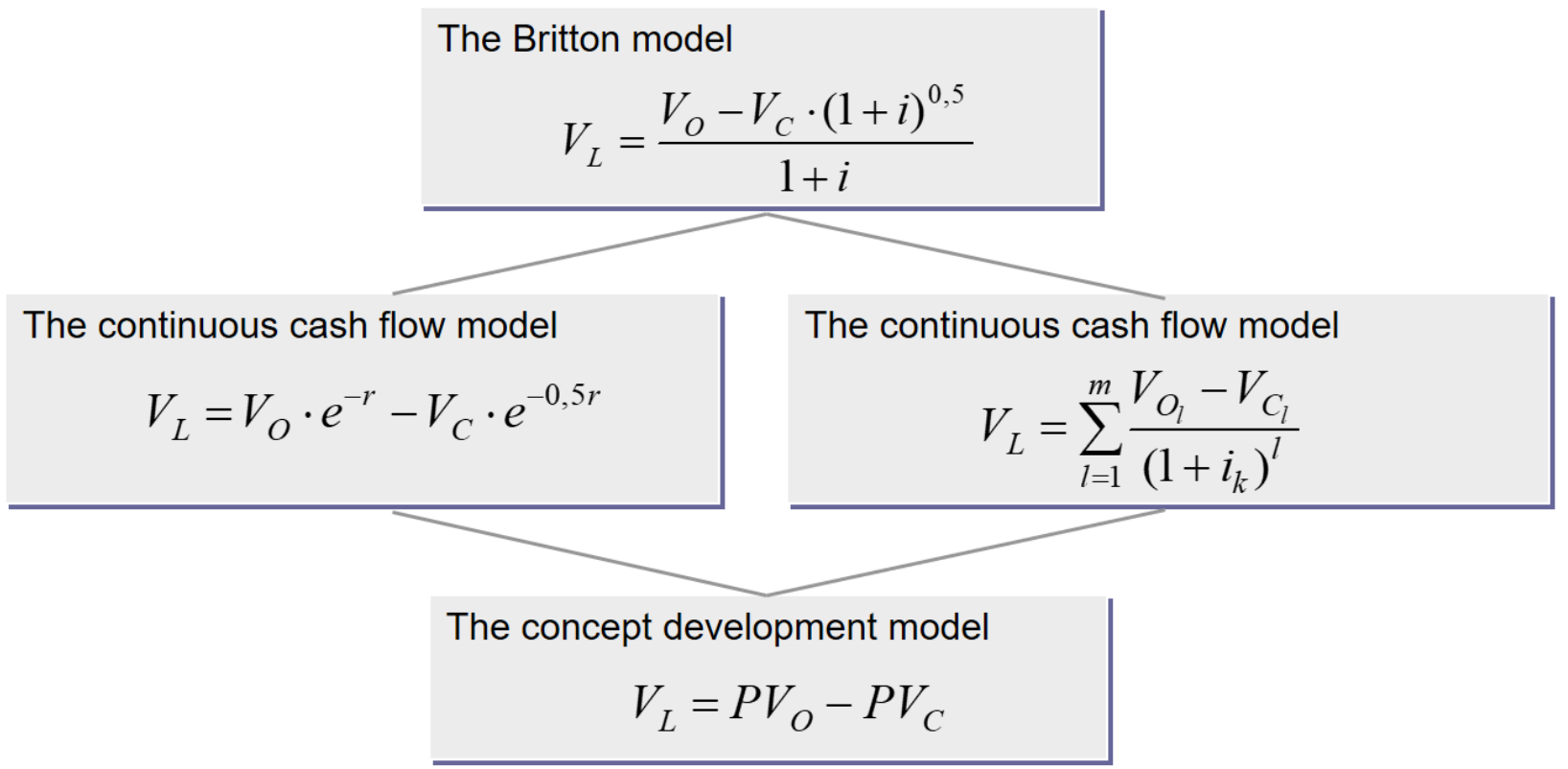

Fig. 8 Determined continuous and discrete cash flows models 
Thus, discounted cash flow models did not violate the residual productivity principle, but required the relevant development risks to be considered:

if cash flows were based on current values and costs (implicit growth model), the risk of their possible change between the valuation date and the development end date should be considered;

if cash flows were based on projected values and costs (explicit growth model), then the risk of such projections should be considered.

6. Sensitivity of the valuation results. The use of discounted cash flow models has another problem with the model uncertainty of land valuation - the high sensitivity of its results to changes in input data, which some experts have questioned the feasibility of using these models in the land value estimate.

Instead, the International Valuation Standards Council, without abandoning the use of deterministic discounted cash flow models, proposes to supplement the result with a sensitivity analysis to establish the scale of the valuation uncertainty [12].

The sensitivity analysis allows you to outline all the land value indications when it is possible to change the benefits and costs associated with its intended use, which indicate the extent of their uncertainty and not the probability of their achievement. Therefore, in our view, deterministic valuing land value models should be supplemented by stochastic cash flow models and thus obtain more holistic and realistic results rather than the only land value indication for which it is unclear how likely it is to be achieved.

Most often, the Monte Carlo method based on a simple random sample is used to construct this type of models [16].

The stochastic discounted cash flow models allow for the use of uncertain data and the plausible picture of possible results that have their statistical interpretation. A probability density plot is used to graphically represent the possible distribution of land values. In addition, if necessary, one can always go to the single indication of the land value, the so-called deterministic equivalent - the sum of all the results obtained, each of which is multiplied by its probability. 


$$
V_{L_{i}}=\rho_{i} \cdot V_{O} \cdot \operatorname{PVF}(i, m)-\varphi_{i} \cdot V_{C_{l}}^{A} \cdot \operatorname{PVAF}(i, m)
$$

where $\rho_{i}$ and $\varphi_{i}$ - the indications of casual rejections of the value of the completed real property and of the annuitized construction value accordingly;

$$
V_{C_{l}}^{A}=F V_{C} \times \frac{i_{k}}{\left(1+i_{k}\right)^{m}-1} \text { - the annuitized construction value }
$$

\section{Fig. 9 The stochastic cash flow model}

7. Option pricing models. The option pricing models are also focused on determining a single value when the input data is volatile. The possibility of their application in the valuation practice has been considered in the International Valuation Standards since 2011 [17].

In land valuation, these models came into use in the 1980s. The most widely used models are the Black-Scholes model, the binomial model and the SamuelsonMcKean model.

Typically, these models are considered as an alternative to discounted cash flow models. However, such a contraposition, in our view, is inappropriate because it neglects the spatiotemporal nature of real property.

The implementation of cash flow discounting to the optional pricing models performed by the authors of the article significantly increased this models operational efficiency. In particular, the Black-Scholes model has proven itself best for determining the land value with high volatility of land-use income; binomial model (Titman model) - for determining the optimum intensity of land use in the situation of inversion of the highest and best use; the Samuelson-McKean model is for determining the hope value as an element of market value that reflects the expectations of market participants for a possible change in current legally permitted use in the future [18]. 
The Black-Scholes model ${ }^{2}$ can be used to estimate any asset that has the features of a real option: the asset value is derived from the income that can be derived from the use of that asset, and the size of the income itself tends to change constantly.

These traits are also fully inherent in land, whose income, even in a stable market situation, will fluctuate all the time under the influence of external (natural or social) conditions. However, the averaging of the expected income, which is characterized by volatility, is not always justified, since this method ignores the possibility of earning land-use income, which will be greater than its average level.

The Black-Scholes model is aimed at generating higher-than-average income. In essence, this model is one of the applications of the partial differential method of dynamically changing value in an effective market, that is, when any changes that affect cash flow in the future immediately lead to a change in the market value of the subject asset.

For the land valuation, the Black-Scholes model inputs will be the average and the coefficient of variation in land-use income (the underlying asset), as well as the cost and duration of contract work required to achieve that income, reflecting, respectively, the price and exercise term of the option.

$$
V_{L}=P V_{O} \cdot F(z 1)-P V_{C} \cdot F(z 2)
$$

where $F($.$) - the function of normal distribution for parameters:$

$$
z 1=\frac{\ln \left(\frac{P V_{O}}{P V_{C}}\right)}{v \sqrt{T}}+\frac{v \sqrt{T}}{2} \quad z 2=\frac{\ln \left(\frac{P V_{O}}{P V_{C}}\right)}{v \sqrt{T}}-\frac{v \sqrt{T}}{2}
$$

$v$ - the coefficient of variation in land-use income;

$T$ - the development period, years

Fig. 10 The Black-Scholes model

\footnotetext{
${ }^{2}$ It was proposed in 1973 by Fisher Black and Myron Scholes to evaluate corporate interests, the value of which depends on factors with a high level of uncertainty, based on the characteristics of the probability dynamics of the factor parameters.
} 
A key component of the Black-Scholes model, which distinguishes it from discounted cash flow models, is the normal distribution functions, whose values allow us to take into account the trend in land-use income (the value of the completed real property) and, thus, reflect this probability range, and therefore the risk of land acquisition. In this case, the land value will increase with increasing volatility of possible land-use income.

The binomial model ${ }^{3}$ is advisable to apply in an unstable market, when the prices of completed real property can both rise and fall, which leads to the problem of optimal intensity of building (or other improvement) of the site, since under such conditions the level of intensity can be decisive when choosing the highest and best use.

To address this, Sheridan Titman in 1985 proposed to evaluate urban land as a development option. In his work, "Urban Land Price Under Uncertainty", he wrote: "The intuition being that a vacant lot can be viewed as an option to purchase one of a number of different possible buildings at exercise prices that are equal to their respective construction costs" $[19$, p. 505]. In this case, the optimal volume of the building - the total area of the apartments being erected - will be determined by future housing prices.

The binomial model applied by Sh. Titman is based on two assumptions:

1) in one interval of the time there can be only two variants of events - the worst and the best;

2) developers are risk-neutral, meaning the likelihood of the best case scenario complements the worst case scenario.

Graphically, this model can be depicted as a binary tree in one interval, reflecting the probable changes in the value of the completed real property and the cost of contracting.

Obviously, in such circumstances, the market land value can be defined as the average risk-weighted probability of land values under the real property prices rise and fall.

\footnotetext{
${ }^{3}$ Proposed in 1979 by J. C. Cox, S. Ross and M. Rubinstein to evaluate financial options
} 


$$
\begin{aligned}
& t=0 \quad t=1 \\
& \begin{aligned}
V_{L}=p S+P V_{C} \underbrace{\pi}_{1-\pi} & V_{L}^{u}=u p S+h P V_{C} \\
V_{L}^{d} & =d p S+h P V_{C}
\end{aligned}
\end{aligned}
$$

Fig. 11 Probable changes in the value of the completed real property and the cost of contracting

Note that when achieving the highest and best use does not depend on the change in land use intensity, the land value at the valuation date will have the same indication as in a stable market situation, despite the fact that its value will increase with positive shifts by the market of the improved real property and will decline with negative trends. Therefore, the use of a binomial model is only appropriate in situations where, within the allowed land use, there is an alternative to the scale of its improvement (the so-called hedge ratio), and the justification of the justified construction costs (strike price) is a condition of adequate valuing of the market land value.

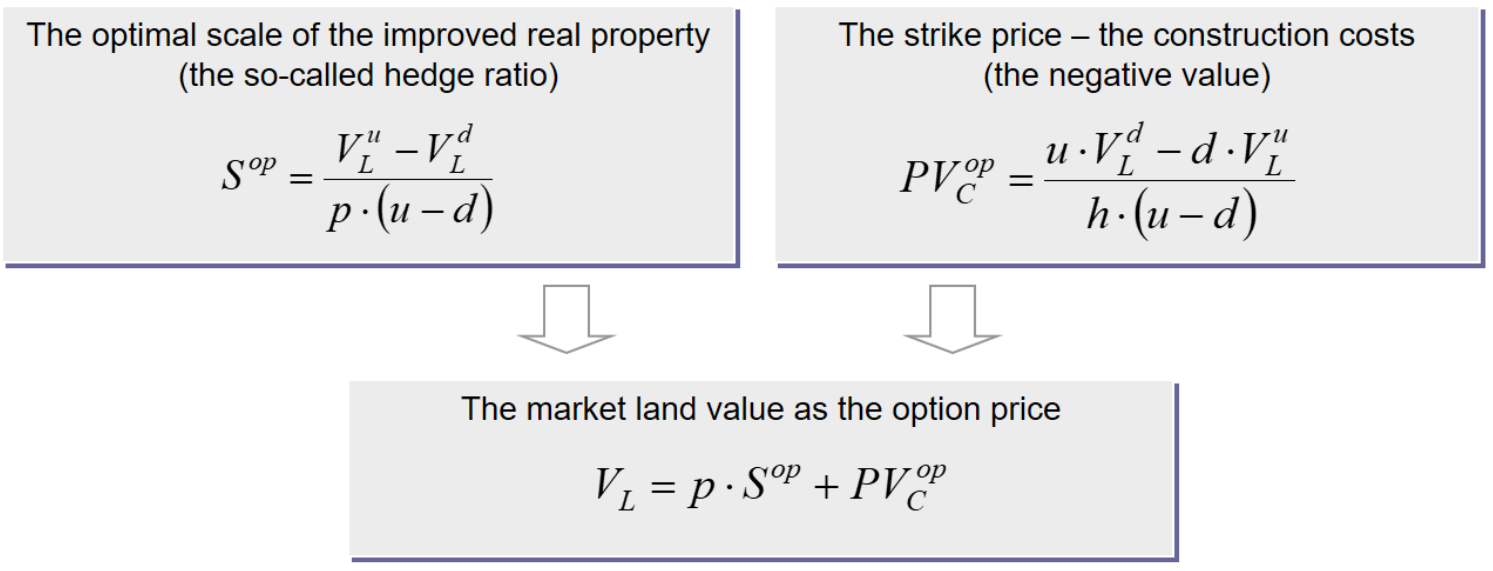

Fig. 12 The binomial model

The Samuelson-McKean model ${ }^{4}$ was first used for land valuation in 1989 by David Geltner to explain the dynamics of changes in existing land use [20].

\footnotetext{
${ }^{4}$ It was proposed in 1965 by Paul Samuelson together with his colleague Henry McKean to evaluate the indefinite American warrants
} 
Using this model, the requirement of IVS 2017, mentioned at the beginning of the article, to implement, together with existing legally permitted land use, the possibility of extending or amending the current regulation may also be implemented. In other words, when determining the land value, when the current zoning rules no longer meet the expectations of market participants, the hope value to the new most efficient use should be taken into account.

The concept of "hope value" is used in English valuation practice [21] and is covered by European Valuation Standards [22, p. 24], where it is interpreted as an element of market value that increases its indication compared to the value of current highest and best use in the event of a potential transition to a new, even more efficient, use.

In this situation, the market value of the land reflects only a fraction of the residual value that the land could receive in the case at its best and most efficient use in the future, since at the valuation date the latter is not yet allowed. Of course, there is a risk that the legalization of such use may take some, rather all in all, for a long time, or not at all.

The Samuelson-McKean model, adapted by the authors to estimate the hope value [18], is a system of equations that give an idea of the market land value with a built-in development option: as the sum of the land value in the current highest and best use and hope value (the first equation) and as a share in the residual land value in the possible highest and best use (the second equation).

The market land value with a built-in development option

$$
\left\{\begin{array}{l}
V_{L}^{m H}=V_{L}^{p u}+V_{L}^{H} \\
V_{L}^{m H}=\left(P V_{O}^{f u}-P V_{C}\right) \cdot\left(\frac{P V_{O}^{G D}}{P V_{O}^{f u}}\right)^{\eta}
\end{array}\right.
$$

Fig. 13 The Samuelson-McKean Model 
The first equation reveals a market value structure with a built-in development option that, like the value of any option, includes the intrinsic value (in our case, the land value in the current highest and best use), and the time value (the hope value paid for the transition possibility to a new, more efficient, use) [23].

The second equation reflects the market land value with a built-in development option as a derivative of the expected benefits of land use in the possible highest and best use and the construction costs required to achieve it. A key parameter of this equation is the ratio of the gross development value to the value of the completed real property, which is adjusted by the elasticity factor, which determines which part of the residual land value at the possible highest and best use will correspond to the market land value with a built-in development option.

Obviously, the use of the Samuelson-McKean model is justified, provided that the land value in current use is less than the land value in possible use, which in fact leads to the hope of the transition to such use. Thus, than higher the indication of the hope value, the higher the probability of passing to the possible highest and best use.

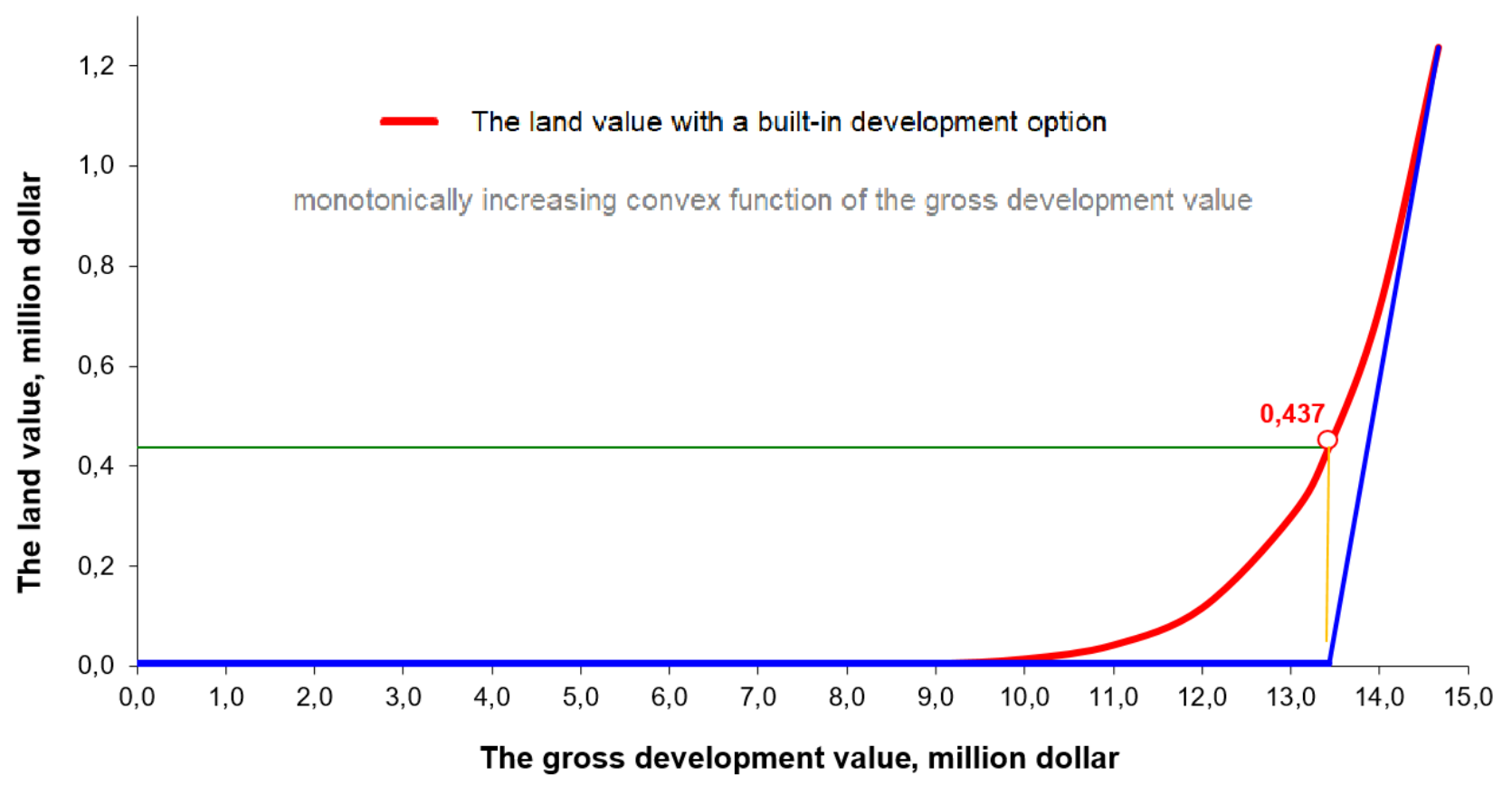

Fig. 14 Changing the market land value with a built-in development option

Theoretically, the option pricing models can be applied to valuing all types of vacant and improved site that are being developed, especially when it comes to choosing their highest and best use. 
Conclusions. The land valuing methods and models discussed in the article have in fact covered the entire history of professional valuation activities, during which numerous valuation procedures for the determination of land value were formed, based on the dominant economic theories at the time.

Despite the evolution and change in the priority of these methods, it can be argued that in each of them, including market comparison models, the principle of residual productivity has been implemented.

That is, the history of the development of valuation methods has confirmed its methodological and theoretical capacity, so its implementation is relevant for domestic valuation practices, which usually ignore the residual nature of land value and the provisions of International Standards, according to which vacant land belongs to the class of development property.

It is impossible to valuing land parcel that, by their physical parameters and legal status, cannot be used except in conjunction with other parcels. All efforts to do so are without merit and are indicative of a misunderstanding of the valuation subject.

This also applies to attempting to give an exclusive character in determining the land value to the method of comparing vacant land sales without taking into account such significant factors as the parameters of their future improvement. Obviously, valuation models of market vacant land comparisons should be complemented (directly or indirectly) by residual productivity models, which will make it impossible to apply any fractional valuation of real property by physical components.

\section{References}

1. Mallinson, M., French, N. (2000) Uncertainty in property valuation: the nature and relevance of uncertainty and how it might be measured. Journal of Property Investment and Finance. 18, 1. P. 13-32.

2. French, N., Gabrielli, L. (2004) The Uncertainty of Valuation. Journal of Property Investment and Finance. 22, 6. P. 484-500. 
3. Adair, A., Hutchison, N., Burgess, J., Roulac S. (2005) The Appraisal of Urban Regeneration Land: A Contemporary Perspective Allowing for Uncertainty. Journal of Property Investment and Finance. 23, 3. P. 213-233.

4. Kucharska-Stasiak, E. (2013) Uncertainty of property valuation as a subject of academic research. Real Estate Management and Valuation. 21, 4. P. 17-25.

5. Leyfer, L. (2013) Harakteristiki tochnosti i neopredelennosti ocenki. Modeli i metody ih opredeleniya [Characteristics of accuracy and uncertainty valuation. Models and methods for their determination]. - Available at: https://docplayer.ru/26446079-Harakteristiki-tochnosti-i-neopredelennosti-ocenkimodeli-i-metody-ih-opredeleniya-vvedenie.html

6. Kalinichenko, Yu. (2014) Koncepcija nevyznachenosti ta jj misce u teoriji ocinjuvannja [The concept of uncertainty and its place in the theory of valuation] // Prometey. 3, 45. P. 56-61.

7. Kalinichenko, Yu. (2016) Identifikacija ta kilkisne vyrazchennja nevyznachenosti ocinky na rynku neruhomosti [Identification and quantification of uncertainty in the real estate market] // Tehnologicheskyi audit i rezervy proizvodstva [Technological audit and production reserves]. 4/5, 30. P. 13-17.

8. Drapikovskyi, O., Ivanova, I. (2018) Problema neoprelelennosti v ocenke zemli i sposoby ee reshenija [The problem of uncertainty in the land valuation and its solving methods]. Monetary valuation of land in Ukraine: achievements, problems, prospects: international scientific-practical conference. Kyiv, November 8-9, 2018, 35-39.

9. Drapikovskyi, O., Ivanova, I. (2019) Immanentnaja neopredelenost ocenki zemli [Immanent uncertainty of land valuation]. Land of Belarus, 1, 27-30.

10. Cost Approach for Tangible Assets: Technical Information Paper 2. (2012). London: IVSC, 27.

11. Eckert, J. K. ed. (1997) Organizacija ocenki i nalogooblozhenija nedvizhimosti [Property Appraisal and Assessment Administration]: in 2 vol. Moscow: Appraisal Academy, 1, 384.

12. International Valuation Standards (2017). London: IVSC. 128. 
13. Dutailly, J-C.(1971) Les valeurs foncieres eu region parisienne. Recherche d'un modele. Cahiers de l'Institut d'Amenagement et d'Urbanisme de la Region parisienne, 25, 31 .

14. IVS 410 Development Property / International Valuation Standards (2019). London: IVSC, 132.

15. Britton, W., Davies, K., Johnson, T. (1989). Modern Methods of Valuation of Land, Houses and Building: 8th Edition. London: Estates Gazette, 768.

16. Treasury Board of Canada Secretariat. (1999). Analiz vygid i vytrat [Benefit-cost Analysis Guide]. Kyiv: Osnovy, 175.

17. International Valuation Standards (2011). London: IVSC, 128.

18. Drapikovskyi, O., Ivanova, I. (2018). Nelvizhimoe imuschestvo i ego stoimost: monografija [Real Property and its value: monography]. LAP LAMBERT Academic Publishing, 159.

19. Titman, Sh. (1985). Urban Land Prices Under Uncertainty. American Economic Review, 75 (3), 505-514.

20. Geltner, D. (1989). On the Use of the Financial Option Price Model to Value and Explain Vacant Urban Land. Journal of the American Real Estate \& Urban Economics Association, 17 (2), 142-158.

21. Shapiro, E., Davies K., Mackmin D. (2013). Modern Methods of Valuation: 11th Edition. London \& New York: Routledge, 246-247.

22. European Valuation Standards: Eighth Edition. (2016): Brussels: TEGoVA, 370.

23. Pomykacz, M., Olmsted, C. (2013). Options in Real Estate Valuation. The Appraisal Journal, Summer, 227-238.

Драпіковський О. І., Іванова І. Б.

РЕАЛІЗАЦІЯ ПРИНЦИПУ ЗАЛИШКОВӦ̈ ПРОДУКТИВНОСТІ В МЕТОДАХ ВИЗНАЧЕННЯ ВАРТОСТІ ЗЕМЛІ

Очінювання землі трунтується на численних принщипах, серед яких провідна роль належить принципу залишкової продуктивності. Відповідно до иъого принципу поточна вартість землі детермінована залишком доходу від ї 
можсливого використання в майбутньому з урахуванням витрат коштів $і$ часу, необхідних для отримання иього доходу. Крім того, принции залишкової продуктивності є основним у розкритті іманентної невизначеності оиінки землі, зумовленою множинністю значень ї̈ вартості, кожне з яких буде достовірним при одних припущеннях і неправдивим в інших випадках.

Застосування иьього принщииу в оцінці землі стало конститутивним у формуванні та розвитку ї̈ методичного апарату.

У статті розглянута еволючія методів визначення вартості землі, заснованих на принципі залишкової продуктивності - від традиџійних методів екстракиії та залишкової капіталізачії до методів дисконтованих грошових потоків, - та проаналізовані основні переваги та обмеження щодо їх застосування в оиіночній практиці. Доведена необхідність переходу від детермінованих до стохастичних моделей грошових потоків та доповнення їх моделями опиіонного ціноутворення, щ̧о найкращим чином відображають сучасне уявлення про залишкову природу вартості землі та враховує притаманну ї̈ оціниі невизначеність.

Ключові слова: залишкова продуктивність землі, невизначеність, детерміновані та стохастичні моделі грошових потоків, моделі опціонного цุіноутворення.

Драпиковский А. И., Иванова И. Б.

\section{РЕАЛИЗАЦИЯ ПРИНЦИПА ОСТАТОЧНОЙ ПРОДУКТИВНОСТИ В} МЕТОДАХ ОПРЕДЕЛЕНИЯ СТОИМОСТИ ЗЕМЛИ

Оченка земли основывается на многочисленных принщипах, среди которых ведущая роль принадлежит принципу остаточной продуктивности. Согласно данному принцииу текущая стоимость земли детерминирована остатком дохода от ее возможного использования в будущем с учетом затрат средств и времени, необходимых для получения этого дохода. Кроме того, принцип остаточной продуктивности является основным в раскрытии имманентной неопределенности оценки земли, обусловленной множественностью значений 
ее стоимости, каждое из которых будет достоверным при одних допущуениях и ложным в иных случаях.

Применение данного принциипа в оценке земли стало конститутивныл в формировании и развитии ее методического аппарата.

В статье рассмотрена эволючия методов определения стоимости земли, построенных на принциипе остаточной производительности - от традициионных методов экстракциии и остаточной капитализации к методам дисконтированных денежных потоков, - и проанализированы основные преимущуества и ограничения по их применению в оченочной практике. Доказана необходимость перехода от детерминированных к стохастическим моделям денежных потоков и дополнения их моделями опциионного цุенообразования, которые наилучшим образом отражают современное представление об остаточной природе стоимости земли и учитьвают присущую ее оценке неопределенность.

Ключевые слова: остаточная продуктивность земли, неопределенность, детерминированные и стохастические модели денежных потоков, модели опцุионного цуенообразования. 